Hydrol. Earth Syst. Sci. Discuss., 4, 2403-2423, 2007 www.hydrol-earth-syst-sci-discuss.net/4/2403/2007/ under a Creative Commons License.
(C) Author(s) 2007. This work is licensed
Hydrology and

Earth System

Sciences
Discussions

Papers published in Hydrology and Earth System Sciences Discussions are under open-access review for the journal Hydrology and Earth System Sciences

HESSD

4, 2403-2423, 2007

$\delta^{18} \mathbf{O}$ and $\delta^{2} \mathbf{H}$

variability in UK rainfall

M. D. Jones et al.

\section{Local $\delta^{18} \mathrm{O}$ and $\delta^{2} \mathrm{H}$ variability in UK rainfall}

M. D. Jones ${ }^{1}$, M. J. Leng ${ }^{1,2}$, C. Arrowsmith ${ }^{2}$, C. Deuchars ${ }^{3}$, J. Hodgson ${ }^{4}$, and T. Dawson ${ }^{5}$

${ }^{1}$ School of Geography, University of Nottingham, UK

${ }^{2}$ NERC Isotope Geosciences Laboratory, British Geological Survey, Keyworth, UK

${ }^{3}$ Waterways Science Group, 2 Repton Road, Long Eaton, UK

${ }^{4}$ British Geological Survey, Keyworth, UK

${ }^{5}$ Meteorological Office, Watnall, UK

Received: 5 July 2007 - Accepted: 16 July 2007 - Published: 25 July 2007

Correspondence to: M. D. Jones (matthew.jones@ nottingham.ac.uk)
Title Page

Abstract

Introduction

Conclusions

References

Tables

Figures

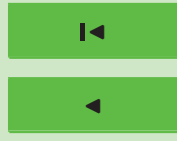

$\rightarrow 1$

Back

Close 


\section{Abstract}

Rainfall collected twice weekly from 3 nearby UK stations between November 2004 and October 2006 allows local differences in $\delta^{18} \mathrm{O}$ and $\delta^{2} \mathrm{H}$ to be observed. Local gradients in $\delta^{18} \mathrm{O}_{p}$ appear to be of the same order of magnitude as national trends, suggesting 5 the spatial $\delta^{18} \mathrm{O}_{p}$ picture is more complicated than the one currently available from sparse GNIP coverage. Comparing data from this study with previous work we find that average $\delta^{18} \mathrm{O}_{p}$ has changed in the UK over the last 20 years concurrent with an average temperature increase although inter-annual controls on the values remain seasonal temperature and the amount of precipitation in each rain event. Climate-isotope relationships observed from the weekly data do not explain the observed decadal scale shifts.

\section{Introduction and background}

The ratios of the stable isotopes of oxygen $\left({ }^{18} \mathrm{O},{ }^{17} \mathrm{O},{ }^{16} \mathrm{O}\right)$ and hydrogen $\left({ }^{2} \mathrm{H},{ }^{1} \mathrm{H}\right)$ change through the various stages of the hydrological cycle due to fractionation processes during evaporation and condensation (e.g. Darling et al., 2006). Light isotopes are preferentially evaporated and heavy isotopes preferentially condensed. The result of these processes is varying values for $\delta^{18} \mathrm{O}$ (the standard notation for describing the ${ }^{18} \mathrm{O}$ to ${ }^{16} \mathrm{O}$ ratio) and $\delta^{2} \mathrm{H}$ (for the ratio of ${ }^{2} \mathrm{H}$ to ${ }^{1} \mathrm{H}$ ) recorded in space and time.

Since these patterns where first described (Craig, 1961, Dansgaard, 1964) a number of further studies have shown common relationships between precipitation $\delta^{18} \mathrm{O}$ and $\delta^{2} \mathrm{H}$ values (from here on $\delta^{18} \mathrm{O}_{p}$ and $\delta^{2} \mathrm{H}_{p}$ ) with changing temperature, precipitation amount, continentality, altitude and latitude (e.g. Rozanski et al., 1993). The theory behind these changes will not be described in detail again here (see Darling et al., 2006 for a recent review) but will be discussed in relation to the results where appropriate.

Global patterns of $\delta^{18} \mathrm{O}_{p}$ and $\delta^{2} \mathrm{H}_{p}$ are now generally well understood thanks to the IAEA GNIP programme (IAEA/WMO 2001; Bowen and Wilkinson, 2002), and regional
HESSD

4, 2403-2423, 2007

$\delta^{18} \mathrm{O}$ and $\delta^{2} \mathrm{H}$

variability in UK rainfall

M. D. Jones et al.

Title Page

Abstract

Introduction

Conclusions

Tables

References

Figures

14

$\rightarrow$

4

Back

Close

Full Screen / Esc

Printer-friendly Version

Interactive Discussion 
studies are often undertaken e.g. Argiriou and Lykoudis (2006). Darling and Talbot (2003) described the controls on isotopes in precipitation in the UK based largely on data from 3 sites (Valentia, Wallingford and Keyworth) at various time scales between 1979 and 1996. They show that the strongest climatic controls on isotope values in 5 UK rainfall were temperature, explaining up to $87 \%$ of the isotope variability for averaged monthly values over 19 years at Wallingford, and rainfall amount, which explained $25 \%$ of the inter-monthly variability over the same time period. They also noted significant altitude effects over high ground of between $-0.3 \%$ ond $-0.2 \% \circ \delta^{18}$ O per $100 \mathrm{~m}$. Changes in continentality between sites lead to differences between the intra-annual ${ }_{10}{ }^{18} \mathrm{O}_{p}$ range and mean weighted values, due to rain out effects from the coastal site at Valentia to the inland sites of Wallingford and Keyworth.

Changes in $\delta^{18} \mathrm{O}_{p}$ are used to understand current (e.g. Bowen and Wilkinson, 2002) and past climate (e.g. Hammurland et al., 2002) and hydrological systems (e.g. Goller et al., 2005; Rodgers et al., 2005 ). Due to logistical constraints our current understanding is based largely on the GNIP network which may only have one or two stations per country, and not necessarily close to sites where $\delta^{18} \mathrm{O}_{p}$ data is required. Where new collection sites are initiated it is often not possible to collect samples for long periods of time to fully understand the local controls and relationships from the nearest GNIP station are therefore used (Jones et al., 2005).

Here we examine the relationship between recent (2004-2006) $\delta^{18} \mathrm{O}_{p}$ and $\delta^{2} \mathrm{H}_{p}$ records from Keyworth $\left(52^{\circ} 52^{\prime} 42^{\prime \prime} \mathrm{N}, 1^{\circ} 4^{\prime} 46^{\prime \prime} \mathrm{W}\right.$; $65 \mathrm{~m}$ a.s.I.) and two new nearby collection stations at Sutton Bonington ( $52^{\circ} 52^{\prime} 42^{\prime \prime} \mathrm{N}, 1^{\circ} 14^{\prime} 46^{\prime \prime} \mathrm{E} ; 48 \mathrm{~m}$ a.s.I.) and Watnall $\left(53^{\circ} 0^{\prime} 20^{\prime \prime} \mathrm{N}, 1^{\circ} 15^{\prime} 5^{\prime \prime} \mathrm{E} ; 117 \mathrm{~m}\right.$ a.s.I.) and compare local variability with the national patterns described by Darling and Talbot (2003). By comparison with previous collection 25 periods this new data also allow us to look at how $\delta^{18} \mathrm{O}_{p}$ patterns observed at Keyworth have changed over the last 20 years.
HESSD

4, 2403-2423, 2007

$\delta^{18} \mathrm{O}$ and $\delta^{2} \mathbf{H}$

variability in UK rainfall

M. D. Jones et al.

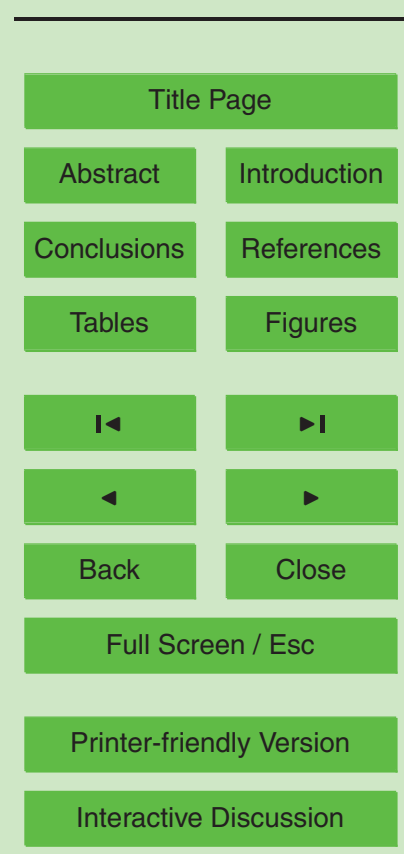




\section{Methodology}

Samples were collected from the 3 sites (Fig. 1) between November 2004 and end October 2006 as part of a larger project monitoring changes in lake water isotope values which will be discussed elsewhere. Rain water was collected twice-weekly from

5 Sutton Bonington and Watnall and weekly from Keyworth using standard 5-inch rain gauges.

All samples for isotope analysis were collected in airtight polyethylene bottles. Unfiltered samples from each of the sites were subsequently treated by $\mathrm{Cr}$ reduction to generate hydrogen for ${ }^{2} \mathrm{H} /{ }^{1} \mathrm{H}$ analysis. For ${ }^{18} \mathrm{O} /{ }^{16} \mathrm{O}$ analysis samples were equilibrated 10 with $\mathrm{CO}_{2}$ using an ISOPREP 18 device. Mass spectrometry was performed on a Micromass IsoPrime $(\delta 2 \mathrm{H})$ and VG SIRA $\left(\delta^{18} \mathrm{O}\right)$ in conjunction with laboratory standards calibrated against VSMOW and SLAP at the NERC Isotope Geosciences Laboratory (NIGL), UK. NIGL participates in the IAEA lead inter-laboratory comparison for stable isotope analysis of precipitation. Results are reported in the usual $\delta$ notation in per 15 mille (\%) versus V-SMOW. Analytical errors are less than $0.05 \%$ for $\delta^{18} \mathrm{O}$ and $1 \%$ ofor $\delta^{2} \mathrm{H}$.

Meteorological observations are made daily at all three sites. At Keyworth observations are made at 09:00 GMT, Sutton Bonington data comes from the hourly observations made by an automated recording station, and data from Watnall was obtained from the British Atmospheric Data Centre and includes total precipitation for the halfweek samples, twice daily measurements of temperature and the average of hourly wind data. The Sutton Bonington instruments were moved to a new, nearby, site in May 2005.

$\delta^{18} \mathrm{O}$ and $\delta^{2} \mathrm{H}$

variability in UK rainfall

M. D. Jones et al.

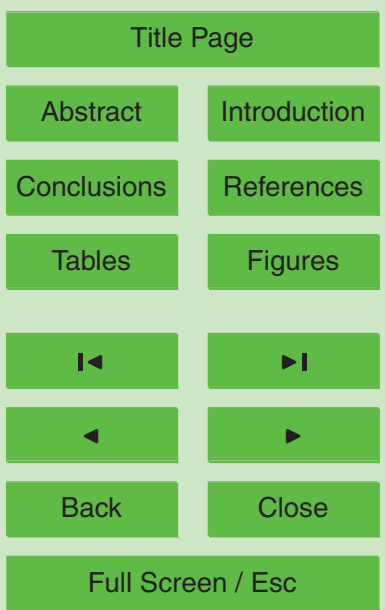

Printer-friendly Version

Interactive Discussion

\section{Results}

$\delta^{18} \mathrm{O}_{p}$ values at the three sites range between $-16.0 \%$ and $+3.5 \%$ (Fig. 2 ). The range at Keyworth $(-13.8$ to $-0.0 \%$ ) is lower than at the other two sites (Sutton Bonington, 
-15.5 to $+3.5 \%$; Watnall -16.0 to $+1.2 \%$ ) and this is probably due to the effect of the lower sampling resolution smoothing shorter rain events. Weighted average $\delta^{18} \mathrm{O}_{p}$ values for the three sites over the common time period April 2005 to September 2006 (not including August and September 2005 for all sites, as there was no rainfall amount 5 data available from Watnall) are $-6.5 \%$ (Sutton Bonington), $-6.6 \%$ (Keyworth) and $-7.2 \%$ (Watnall).

Although the Keyworth record is sampled at a lower resolution than the other two sites there are similarities between the three $\delta^{18} \mathrm{O}_{p}$ time series (Fig. 2). Values for $\delta^{2} \mathrm{H}$ are not shown due to the strong co-variation between the two data sets. In general 10 summer precipitation is more positive (heavier) than winter values (Table 1) although there is a high frequency signal on top of the seasonal sinusoidal variation. Some individual events are visible at all three sites, particularly large negative excursions at days 147, 202 and 721.

There are similarities between the oxygen-hydrogen $\left(\delta^{2} \mathrm{H} v . \delta^{18} \mathrm{O}\right)$ relationships be15 tween the three sites (Fig. 3). The changes in gradient, between 7.3 and 7.5, and intercept values (3.0 to 4.8) are within analytical errors and are therefore considered to be the same. There are differences between summer (JJA) and winter (DJF) meteoric water lines (Table 1). Summer gradients are much shallower at all 3 sites (6.6-6.9) with much lower intercepts $(0.2-1.6)$ relative to the other seasons (Table 1$)$.

\section{Discussion}

\subsection{Climate controls on $\delta^{18} \mathrm{O}_{p}$}

Comparison of the $\delta^{18} \mathrm{O}_{p}$ data with meteorological observations at the three sites allows us to look at the controls on the isotope values of precipitation. Darling and Talbot (2003) showed that different climate- $\delta^{18} \mathrm{O}_{p}$ relationships are found when using differ25 ent sampling resolutions. Data from the GNIP database, for example, is usually given as monthly averages. Here we use the average meteorological conditions over the
HESSD

4, 2403-2423, 2007

$\delta^{18} \mathrm{O}$ and $\delta^{2} \mathrm{H}$

variability in UK rainfall

M. D. Jones et al.

Title Page

Abstract

Introduction

Conclusions

Tables

References

Figures

14

$\rightarrow$

4

Back

Close

Full Screen / Esc

Printer-friendly Version

Interactive Discussion 
isotope sample period for each of the three sites i.e. weekly or half-weekly. As hourly data is available from Sutton Bonington (our longest data set) we use this station to look at differences in the climate- $\delta^{18} \mathrm{O}_{p}$ relationships when using only the conditions during rainfall hours, and to look at the relationships when using monthly average val5 ues. By looking at relationships over various time scales we hope to explain more of the variability in $\delta^{18} \mathrm{O}_{p}$.

Comparing each $\delta^{18} \mathrm{O}$ value with the average meteorological conditions during the sample period (Table 2) shows that the strongest relationships with $\delta^{18} \mathrm{O}_{p}$ are with temperature and the amount of precipitation, as found by Darling and Talbot (2003).

10 Precipitation amount shows more control in summer and winter compared to the transitional seasons, explaining $50 \%$ of the $\delta^{18} \mathrm{O}_{p}$ variability in summer precipitation at Watnall, $38 \%$ at Sutton Bonington and $28 \%$ in Keyworth. Temperature explains very little variability in autumn and summer values but can explain up to $26 \%$ of the variability (Watnall) when all the samples are taken into account. Wind direction and wind speed 5 explain very little of the variability.

Kohn and Welker (2005) show that isotope-climate relationships can change when looking only at the meteorological conditions at the time of rainfall. Using this data from Sutton Bonington no new relationships are apparent (Table 3) although slightly more of the variance is explained. 26 of the 142 samples from Sutton Bonington are from 20 individual rainfall events. Using only these samples only $16 \%$ of the $\delta^{18} \mathrm{O}_{p}$ variability is explained by rainfall amount and only $4 \%$ by temperature.

The wind direction during rainfall events is largely from the south west, although there is a second dominant direction from the north east (Fig. 4). Taking the average wind direction over the sample periods only 6 out of the 146 sample have an average north east ( 0 to 45 degrees) wind direction, compared to 36 from the south west (180 to 225 degrees). Mean values for these two groups are different, $-3.4 \pm 2.4 \%$ and $-5.3 \pm 2.8 \%$ 。 respectively (mean value \pm standard deviation), although there are too few samples form the north east to make significant statistical comparisons.

Taking monthly average values, as in the GNIP database, none of the weighted av-

HESSD

4, 2403-2423, 2007

\section{$\delta^{18} \mathbf{O}$ and $\delta^{2} \mathbf{H}$ \\ variability in UK rainfall}

M. D. Jones et al.

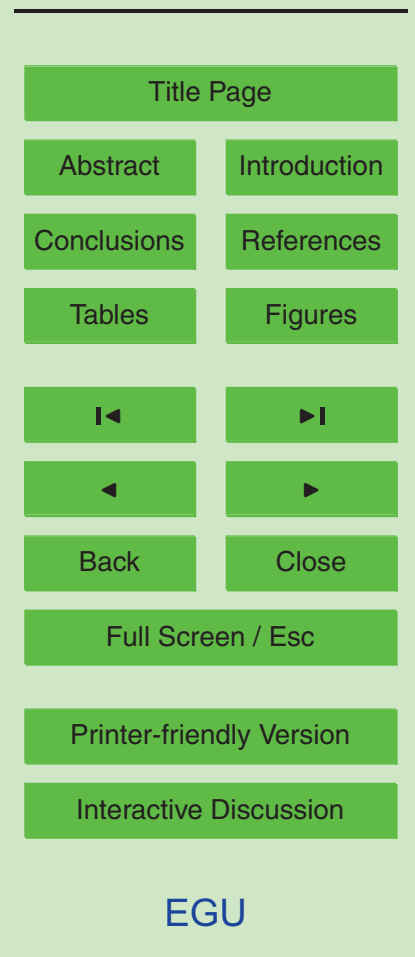


erage $\delta^{18} \mathrm{O}_{p}$ variability is explained by the amount of monthly rainfall whereas average monthly temperatures explain 39\% of the variability. Figure 5 shows the differences in the relationships between the individual sample data and monthly data from Sutton Bonington. Not only does the strength of the relationships alter but also the gradients 5 of change. The $\delta^{18} \mathrm{O}_{p}$ temperature relationship for the monthly data is $0.25 \%$ o per ${ }^{\circ} \mathrm{C}$, compared to $0.18 \%$ per ${ }^{\circ} \mathrm{C}$ for the half weekly samples. These gradients are similar to those found previously for the UK (Darling and Talbot, 2003).

The data suggest that $\delta^{18} \mathrm{O}_{p}$ variability at these three stations is due to short term changes in the amount of precipitation on top of longer term, seasonal, changes in temperature. These results are similar to those found by Darling and Talbot (2003) and show that at least on an intra-annual level there have be no changes in the controls on UK $\delta^{18} \mathrm{O}_{p}$ over the last 10 years.

$$
4.2 \delta^{2} \mathrm{H}_{p} \text { v. } \delta^{18} \mathrm{O}_{p}
$$

The differences between the 3 sites for the gradient and intercept values of the meteoric 15 water lines are greater than those between Valentia and Keyworth (Darling and Talbot, 2003); however given the errors on the $\delta^{2} \mathrm{H}$ data in particular we can not draw any conclusions from these differences. The values for $\mathrm{A}$ and $\mathrm{B}$ (where $\delta \mathrm{D}=\mathrm{A} \delta^{18} \mathrm{O}+\mathrm{B}$ ) are similar to those reported by Darling and Talbot (2003) for the period 1989-1992 and 1995-1996. Given that thee values are controlled by the condensation of atmospheric 20 vapour and relative humidity at the source area respectively the data suggest that there has been no major shift in the UK rainfall source area in the past decade.

\subsection{Spatial variability in $\delta^{18} \mathrm{O}_{p}$}

There are significant differences between the mean weighted average values of $\delta^{18} \mathrm{O}_{p}$ from the 3 sites (Table 1) with the value from Watnall $(-7.2 \%)$ much less than that at Sutton Bonington (-6.5\%०) and Keyworth (-6.6\%०). The difference in height of the Watnall station (117 masl compared to $65 \mathrm{~m}$ a.s.I. for Keyworth and 48 masl for Sutton
HESSD

4, 2403-2423, 2007

$\delta^{18} \mathrm{O}$ and $\delta^{2} \mathrm{H}$

variability in UK rainfall

M. D. Jones et al.

Title Page

Abstract

Introduction

Conclusions

Tables

References

Figures

14

$\rightarrow$

4

Back

Close

Full Screen / Esc

Printer-friendly Version

Interactive Discussion 
Bonington) is not enough to explain this difference. Given a height effect of between -0.2 and $-0.3 \%$ o per $100 \mathrm{~m}$ (Darling and Talbot, 2003) only 0.1 to $0.2 \%$ of the difference can be explained.

The most likely cause of spatial change in $\delta^{18} \mathrm{O}_{p}$ would be due to rainout, with lighter 5 rain falling further along the predominant rain track as heavy isotopes are preferentially rained out. As dominant winds are from the south and west the rainout hypothesis would fit the data. Of interest is the size of the rainout gradient over this small region. Darling and Talbot (2003) showed that the difference in mean weighted $\delta^{18} \mathrm{O}$ between Valentia and Keyworth, a distance of $650 \mathrm{~km}$, is approximately $2 \%$. This difference was attributed to rainout. Our data show a change of $0.7 \%$ over just $20 \mathrm{~km}$.

This much steeper local $\delta^{18} \mathrm{O}_{p}$ gradient, compared to the one observed nationally, has implications for understanding the way rain bearing air masses develop across the UK. Some difference may be explained by the differences in northeast and southwest rains although for the few samples here northeast rains are more positive than those from the southwest, opposite to the spatial trend observed.

The local $\delta^{18} \mathrm{O}_{p}$ gradient suggests that air masses may travel for some distance overland before any rain falls, or that new moisture is picked up on route. If this is the case the differences between mean weighted $\delta^{18} \mathrm{O}_{p}$ values in Valentia and Keyworth must be the result of much more complex processes than simply rainout. A much 20 denser network of sampling stations across a much wider area is needed to be able to investigate these patterns further.

\subsection{Long term change}

Prior to this study rainfall isotope values are available from Keyworth between 1985 and 1996 (Darling and Talbot, 2003). Our new data allow us to observe any changes in patterns over the last 20 years. The equivalent 19 months data were compared for the periods 1985-1986, 1995-1996 and 2005-2006 (Table 4). The weekly data set from the current study was transformed to monthly data using weighted average values.

$\delta^{18} \mathrm{O}_{p}$ is $1.3 \%$ heavier in the current study compared to the earlier time periods. 2410
HESSD

4, 2403-2423, 2007

\section{$\delta^{18} \mathbf{O}$ and $\delta^{2} \mathbf{H}$ \\ variability in UK rainfall}

M. D. Jones et al.

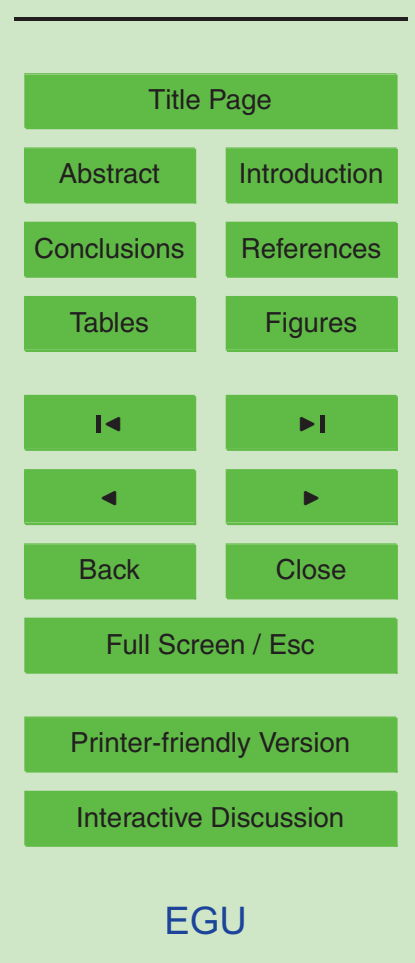


Given the relationship of $\delta^{18} \mathrm{O}_{p}$ with temperature, at least on longer time scales, this would be expected as the 2005-2006 period is considerably warmer than the other two (Table 4). However the size of the change $(1.3 \%$ ) is $0.8 \%$ ogreater than would be expected from the $\delta^{18} \mathrm{O}_{p}$ temperature relationships from the monthly data. It would be expected that the 1995-1996 period would also be heavier than 1985-1986 given the temperature trend however the values remain the same from 1985-1986 despite the $1.1^{\circ} \mathrm{C}$ increase in average temperature. 1995 to 1996 was much drier, although this can't explain the difference between the mean values and that expected with the change in temperature, because drier conditions should also push $\delta{ }^{18} \mathrm{O}_{p}$ values more 10 positive, according to the $\delta^{18} \mathrm{O}_{p}$ precipitation amount relationships observed in the bi-weekly data.

The $\delta^{18} \mathrm{O}-\delta^{2} \mathrm{H}$ relationship is also different during 1995-1996 (Fig. 6) when compared to the other collection periods. For any given value of $\delta^{2} \mathrm{H}$ the $\delta^{18} \mathrm{O}$ values were approximately $0.7 \%$ o lighter than during the other 2 time periods. Correcting the weighted average $1995-1996 \delta^{18} \mathrm{O}_{p}$ data by $0.7 \%$ o would lead to average values midway between 1985-1986 and 2005-2006 and fit the temperature trend. It is unclear what conditions would lead to this difference, and 3 time periods is a small number to draw any significant conclusions, however it would appear that global temperature trends are affecting the $\delta^{18} \mathrm{O}$ values of UK precipitation, although other factors are also important.

\section{Summary and conclusions}

Average $\delta^{18} \mathrm{O}_{p}$ has changed in the UK over the last 20 years concurrent with an average temperature increase although the inter-annual controls on the values remain seasonal temperature and the amount of precipitation in each rain event. How temperature and precipitation amount control the longer, inter-decadal variability is still unclear as the patterns explained by intra-annual variability do not explain the long-term trends.
HESSD

4, 2403-2423, 2007

$\delta^{18} \mathrm{O}$ and $\delta^{2} \mathrm{H}$

variability in UK rainfall

M. D. Jones et al.

Title Page

Abstract

Introduction

Conclusions

Tables

References

Figures

14

$\rightarrow$

4

Back

Close

Full Screen / Esc

Printer-friendly Version

Interactive Discussion 
This suggests that relationships between temperature, rainfall amount and isotopes on a month by month basis are not valid for interpreting longer term changes. This has important implications for interpreting palaeorecords of isotope change.

Local gradients in $\delta^{18} \mathrm{O}_{p}$ appear to be of the same order of magnitude as national 5 trends, suggesting the spatial picture is more complicated than the one currently available with sparse GNIP coverage. Although the current sampling stations allow global or continental patterns to be observed they do not fully explain variations on the $\mathrm{km}$ scale. Extrapolation from near by GNIP stations for local studies may therefore not be always appropriate without local rainfall sampling.

10 Acknowledgements. We thank D. Waite for collecting the rainfall samples at Watnall. We also thank the NERC Isotope Geosciences Facilities (Grant IP/855/0505) and the School of Geography, University of Nottingham for funding this work.

\section{References}

Argiriou, A. A. and Lykoudis, S.: Isotopic composition of precipitation in Greece, J. Hydrol., 327, 486-495, 2006.

Bowen, G. J. and Wilkinson, B.: Spatial distribution of $\delta^{18} \mathrm{O}$ in meteoric precipitation, Geology, 30, 315-318, 2002.

Craig, H.: Isotopic variations in meteoric waters, Science, 133, 1702-1703, 1961.

Dansgaard, W.: Stable Isotopes in Precipitation, Tellus, 16, 436-468, 1964.

Darling, W. G., Bath, A. H., Gibson, J. J., and Rozanski, K.: Isotopes in Water. In: Leng, M. J. (Ed.): Isotopes in Palaeoenvironmental Research, Springer, Dordrecht, 2006.

Darling, W. G. and Talbot, J. C.: The $\mathrm{O}$ and $\mathrm{H}$ stable isotopic composition of fresh waters in the British Isles. 1. Rainfall, Hydrol. Earth. Syst. Sci., 7, 163-181, 2003.

Goller, R., Wilcke, W., Leng, M. J., Tobschall, H. J., Wagner, K., Valarezo, C., and Zech, W.:

Tracing water paths through small catchments under a tropical montane rain forest in south Ecuador by an oxygen isotope approach, J. Hydrol., 308, 67-80, 2005.

Gonfiantini, R.: Environmental isotopes in lake studies, in: Handbook of Environmental Isotope Geochemistry, edited by: Fritz, P. and Fontes, J.-C., 2B, Elsevier, Amsterdam, 119-168, 1986.

\section{HESSD}

4, 2403-2423, 2007

$\delta^{18} \mathrm{O}$ and $\delta^{2} \mathbf{H}$

variability in UK

rainfall

M. D. Jones et al.

Title Page

Abstract

Introduction

Conclusions

References

Tables

Figures

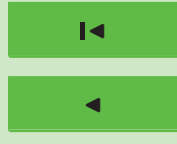

$\rightarrow 1$

Back

Close

Full Screen / Esc

Printer-friendly Version

Interactive Discussion 
Hammarlund, D., Barnekow, L., Birks, H. J. B., Buchardt, B., and Edwards, T. W. D.: Holocene changes in atmospheric circulation recorded in the oxygen-isotope stratigraphy of lacustrine carbonates from northern Sweden, Holocene, 12, 233-248, 2002.

IAEA/WMO. Global Network of Isotopes in Precipitation. The GNIP Database, Accessible at: http://isohis.iaea.org, 2001.

Jones, M. D., Leng, M. J., Roberts, C. N., Türkes, M. ,and Moyeed, R.: A coupled calibration and modelling approach to the understanding of dry-land lake oxygen isotope records, $\mathrm{J}$. Paleolimnol., 34, 391-411, 2005.

Kohn, M. J. and Welker, J. M.: On the temperature correlation of $\delta^{18} \mathrm{O}$ in modern precipitation. Earth Planet. Sci. Lett., 231, 87-96, 2005.

Rodgers, P., Soulsby, C., and Waldron, S.: Stable isotope tracers as diagnostic tools in upscaling flow path understanding and residence time estimates in a mountainous mesoscale catchment, Hydrol. Process., 19, 2291-2307, 2005.

Rozanski, K., Araguas-Araguas, L., and Gonfiantini, R.: Isotopic patterns in modern global

78, American Geophysical Union, 1993.

HESSD

4, 2403-2423, 2007

$\delta^{18} \mathbf{O}$ and $\delta^{2} \mathrm{H}$

variability in UK rainfall

M. D. Jones et al.

Title Page

Abstract

Introduction

Conclusions

References

Tables

Figures

14

\section{$>1$}

4

Back

Close

\section{Full Screen / Esc}

Printer-friendly Version

Interactive Discussion 


\section{HESSD}

4, 2403-2423, 2007

Table 1. Summary of $\delta^{18} \mathrm{O} \vee \delta^{2} \mathrm{H}$ relationship for the three sites, using the relationship $\delta \mathrm{D}=\mathrm{A}$ $\delta^{18} \mathrm{O}+\mathrm{B}$., and weighted average $\delta^{18} \mathrm{O}$ values.

\begin{tabular}{llll}
\hline & A & B & Weighted average $\delta^{18} O$ \\
\hline Keyworth & & & \\
All Samples $(n=81)$ & 7.4 & 3.7 & -6.6 \\
Winter $(n=12)$ & 8.0 & 10.8 & -9.1 \\
Spring $(n=25)$ & 7.8 & 4.7 & -6.8 \\
Summer $(n=24)$ & 6.4 & 1.6 & -5.5 \\
Autumn $(n=20)$ & 7.7 & 5.5 & -7.1 \\
Watnall & & & \\
All Samples $(n=118)$ & 7.3 & 2.8 & -7.2 \\
Winter $(n=19)$ & 8.1 & 10.9 & -9.1 \\
Spring $(n=33)$ & 8.1 & 7.2 & -7.3 \\
Summer $(n=35)$ & 6.6 & 1.6 & -6.0 \\
Autumn $(n=31)$ & 7.6 & 6.7 & -7.5 \\
Sutton Bonington & & & \\
All Samples $(n=142)$ & 7.5 & 4.8 & -6.4 \\
Winter $(n=36)$ & 7.8 & 9.7 & -7.3 \\
Spring $(n=40)$ & 7.8 & 4.2 & -6.7 \\
Summer $(n=33)$ & 6.9 & 0.2 & -5.6 \\
Autumn $(n=31)$ & 7.8 & 6.8 & -6.9 \\
\hline
\end{tabular}

$\delta^{18} \mathrm{O}$ and $\delta^{2} \mathbf{H}$ variability in UK rainfall

M. D. Jones et al.

\section{Title Page}

Abstract

Introduction

Conclusions

References

Tables

Figures

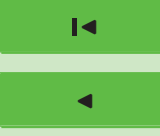

Back

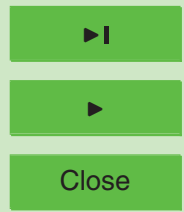

Full Screen / Esc

Printer-friendly Version

Interactive Discussion 
Table 2. Strength of relationship $\left(r^{2}\right)$ between $\delta^{18} \mathrm{O}_{p}$ and selected meteorological variables for all samples. Meteorological variables are averaged over the sample time period, except rainfall (sum).

\begin{tabular}{llllll}
\hline & Precipitation & $\begin{array}{l}\text { Minimum } \\
\text { Temp. }\end{array}$ & $\begin{array}{l}\text { Maximum } \\
\text { Temp. }\end{array}$ & $\begin{array}{l}\text { Wind } \\
\text { Direction }\end{array}$ & $\begin{array}{l}\text { Wind } \\
\text { Speed }\end{array}$ \\
\hline Keyworth & & & & & \\
All samples & 0.04 & 0.20 & 0.25 & 0.01 & 0.01 \\
Winter & 0.06 & 0.04 & 0.19 & 0.09 & 0.05 \\
Spring & 0.01 & 0.24 & 0.15 & 0.03 & 0.00 \\
Summer & 0.28 & 0.00 & 0.09 & 0.16 & 0.02 \\
Autumn & 0.23 & 0.00 & 0.02 & 0.04 & 0.19 \\
Watnall & & & & & \\
All samples & 0.15 & 0.19 & 0.26 & 0.00 & 0.02 \\
Winter & 0.37 & 0.01 & 0.03 & 0.01 & 0.00 \\
Spring & 0.09 & 0.08 & 0.15 & 0.04 & 0.00 \\
Summer & 0.50 & 0.08 & 0.16 & 0.07 & 0.01 \\
Autumn & 0.14 & 0.04 & 0.07 & 0.01 & 0.02 \\
Sutton Bonington & & & Temp. & & \\
All samples & 0.11 & & 0.09 & 0.01 & 0.00 \\
Winter & 0.16 & & 0.12 & 0.13 & 0.00 \\
Spring & 0.15 & & 0.08 & 0.00 & 0.00 \\
Summer & 0.38 & & 0.03 & 0.00 & 0.05 \\
Autumn & 0.12 & & 0.03 & 0.00 & 0.00 \\
\hline
\end{tabular}

HESSD

4, 2403-2423, 2007

$\delta^{18} \mathrm{O}$ and $\delta^{2} \mathbf{H}$

variability in UK rainfall

M. D. Jones et al.

Title Page

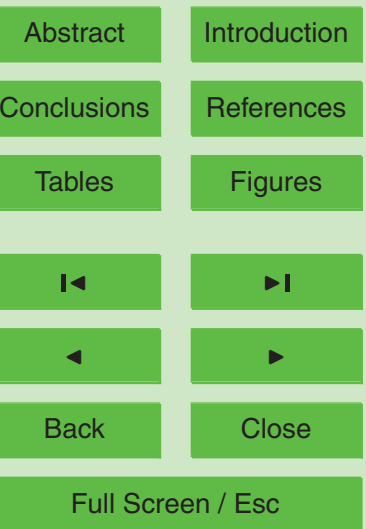

Printer-friendly Version

Interactive Discussion 


\section{HESSD}

4, 2403-2423, 2007

$\delta^{18} \mathrm{O}$ and $\delta^{2} \mathrm{H}$ variability in UK rainfall

Table 3. Strength of relationship $\left(r^{2}\right)$ between $\delta^{18} \mathrm{O}_{p}$ and selected meteorological variables for conditions during rainfall hours at Sutton Bonington. Meteorological variables are averaged over the sample time period, except rainfall (sum).

\begin{tabular}{lllll}
\hline & Precipitation & Temp. & $\begin{array}{l}\text { Wind } \\
\text { direction }\end{array}$ & $\begin{array}{l}\text { Wind } \\
\text { speed }\end{array}$ \\
\hline All samples & 0.12 & 0.11 & 0.01 & 0.02 \\
Winter & 0.19 & 0.14 & 0.17 & 0.03 \\
Spring & 0.11 & 0.04 & 0.01 & 0.01 \\
Summer & 0.38 & 0.10 & 0.04 & 0.00 \\
Autumn & 0.17 & 0.12 & 0.02 & 0.00 \\
\hline
\end{tabular}

Title Page

Abstract

Introduction

Conclusions

References

Tables

Figures

14

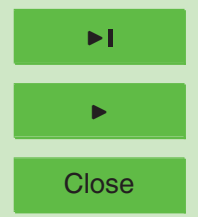

Back 


\section{HESSD}

4, 2403-2423, 2007

$\delta^{18} \mathrm{O}$ and $\delta^{2} \mathrm{H}$ variability in UK rainfall

M. D. Jones et al.

Table 4. Long term variability in weighted average $\delta^{18} \mathrm{O}_{p}$ from Keyworth. Values calculated from March year 1 to September year 2. Temperature values are from Sutton Bonington as no data are available for Keyworth in 1985 or 1986.

\begin{tabular}{llll}
\hline Time Period & $\begin{array}{l}\text { Weighted average } \delta^{18} \mathrm{Op} \\
(\%)\end{array}$ & $\begin{array}{l}\text { Mean Average Temperature } \\
\left({ }^{\circ} \mathrm{C}\right)\end{array}$ & $\begin{array}{l}\text { Total Rainfall } \\
(\mathrm{mm})\end{array}$ \\
\hline $1985-1986$ & -7.8 & 9.5 & 898 \\
$1995-1996$ & -7.8 & 10.6 & 661 \\
$2005-2006$ & -6.5 & 11.5 & 897 \\
\hline
\end{tabular}

Title Page

Abstract Introduction

Conclusions

References

Tables

Figures

14

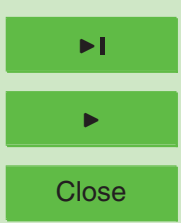

Back

Printer-friendly Version

Interactive Discussion 


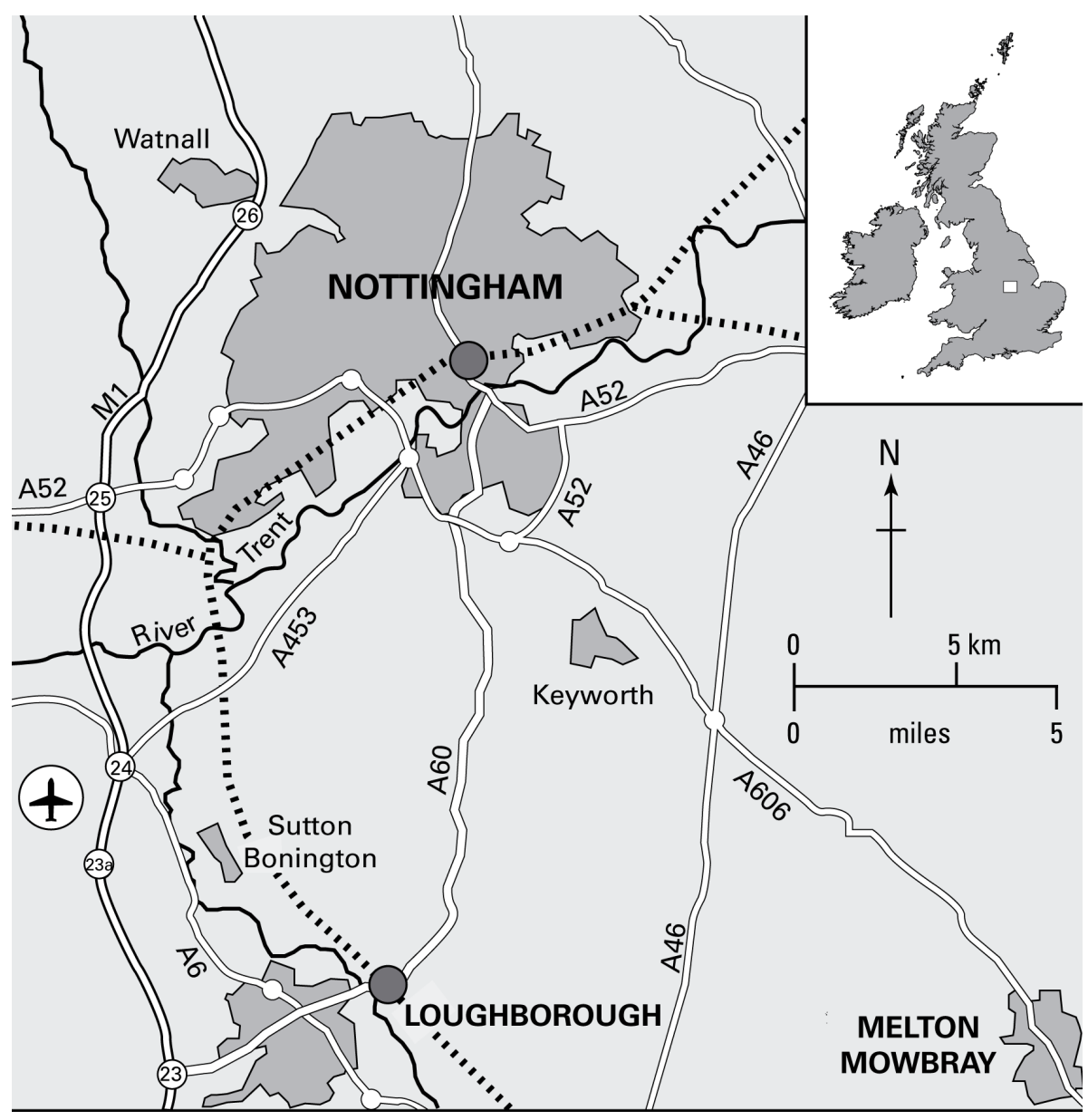

Fig. 1. Location map of the three sites used in this study and their relative position in the UK (inset).

\section{HESSD}

4, 2403-2423, 2007

$\delta^{18} \mathrm{O}$ and $\delta^{2} \mathrm{H}$ variability in UK rainfall

M. D. Jones et al.

Title Page

Abstract

Introduction

Conclusions

References

Tables

Figures

14

4

Back

Close

\section{Full Screen / Esc}

Printer-friendly Version

Interactive Discussion

EGU 


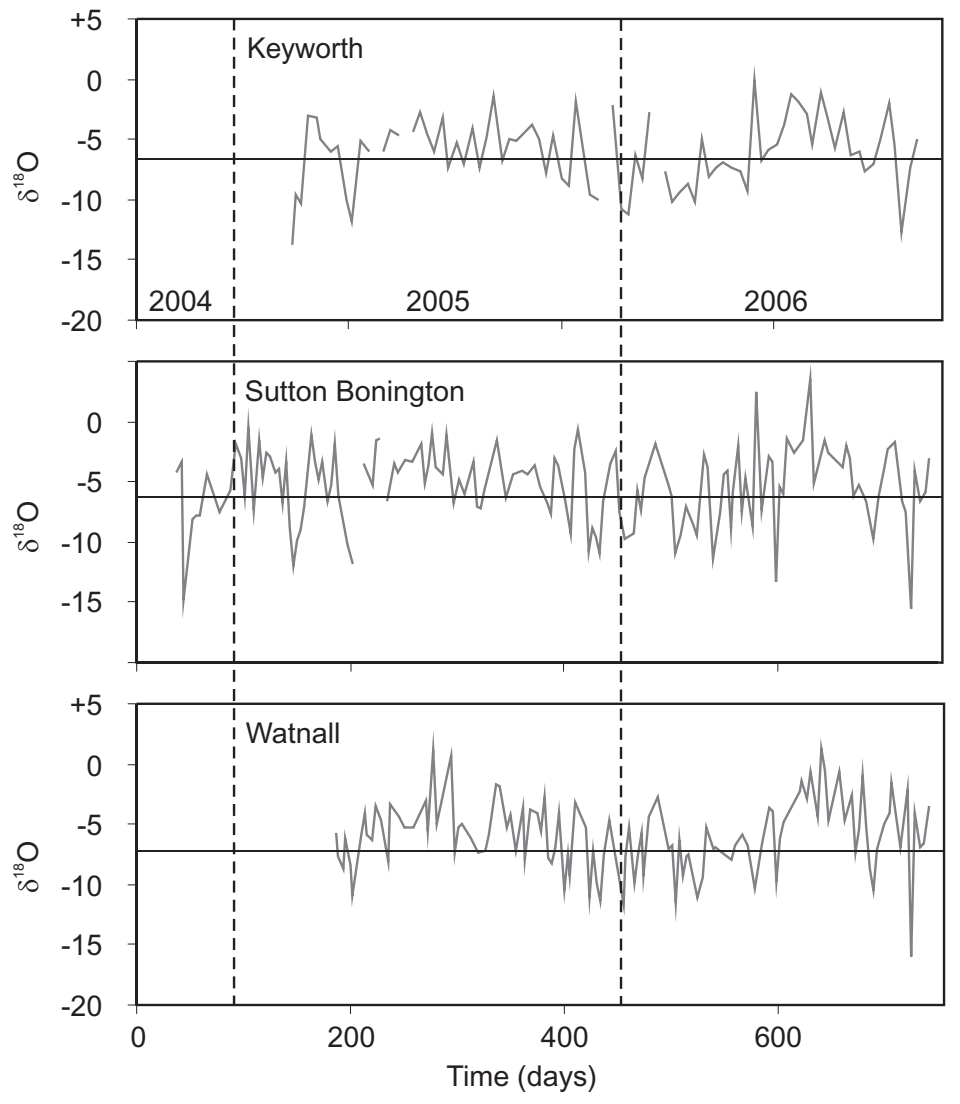

Fig. 2. Time series of $\delta^{18} \mathrm{O}_{p}$ from the three sites. The thick horizontal line marks the weighted average $\delta^{18} \mathrm{O}_{p}$ for each site.

\section{HESSD}

4, 2403-2423, 2007

\section{$\delta^{18} \mathbf{O}$ and $\delta^{2} \mathbf{H}$} variability in UK rainfall

M. D. Jones et al.

\section{Title Page}

Abstract

Introduction

Conclusions

References

Tables

Figures

14

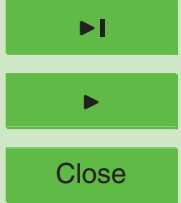

Back

\section{Full Screen / Esc}

Printer-friendly Version

Interactive Discussion 


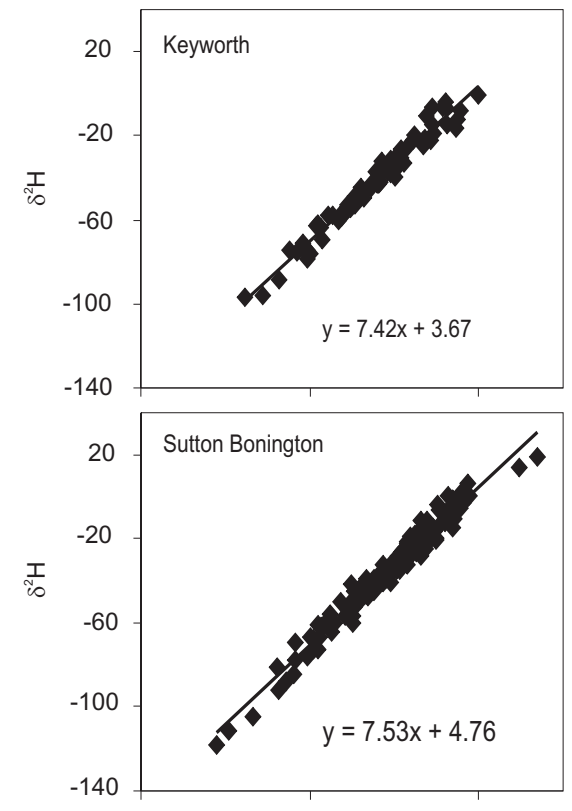

\section{HESSD}

4, 2403-2423, 2007

$\delta^{18} \mathrm{O}$ and $\delta^{2} \mathbf{H}$ variability in UK rainfall

M. D. Jones et al.

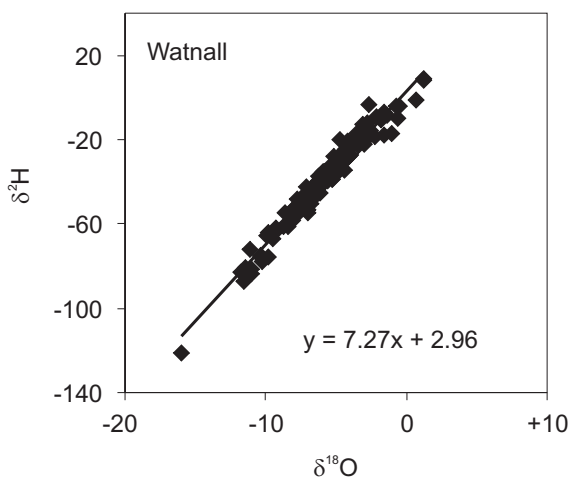

Title Page

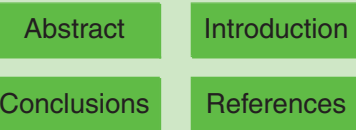

Tables

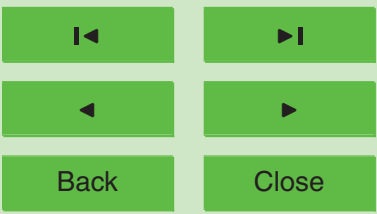

Full Screen / Esc

Printer-friendly Version

Interactive Discussion

Fig. 3. $\delta^{2} \mathrm{H}_{p}$ v. $\delta^{18} \mathrm{O}_{p}$ for the three sites.

2420 


\section{HESSD}

4, 2403-2423, 2007

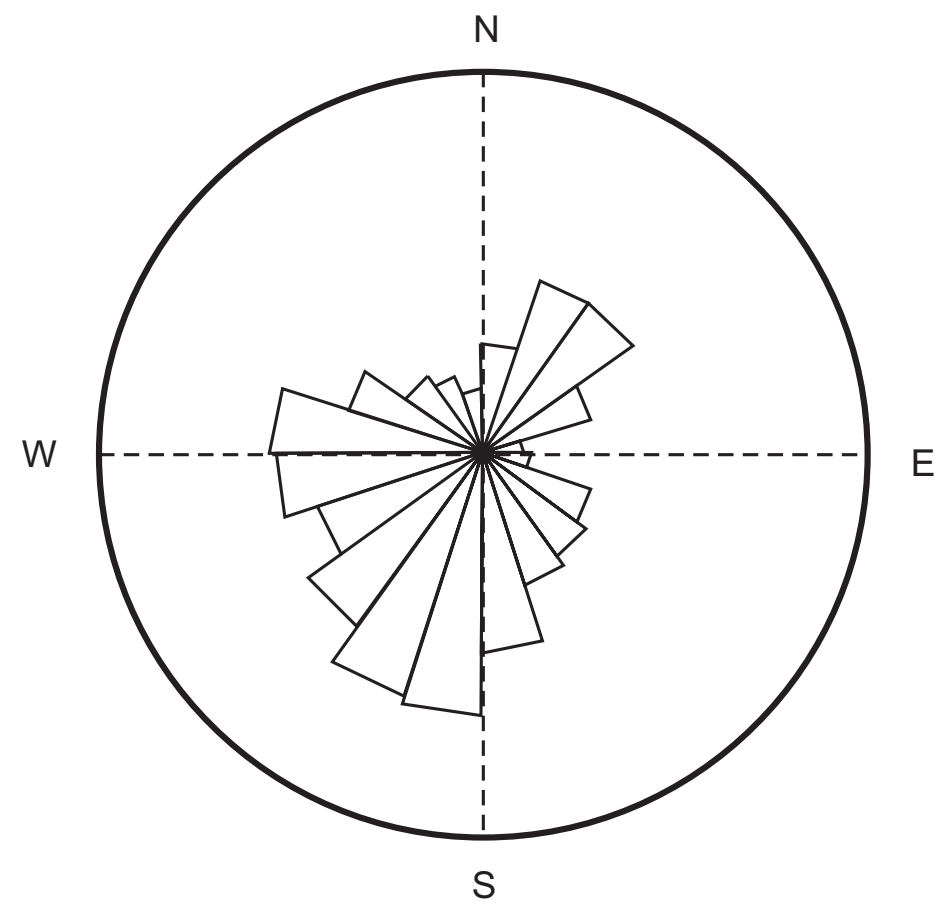

$\delta^{18} \mathrm{O}$ and $\delta^{2} \mathbf{H}$ variability in UK rainfall

M. D. Jones et al.

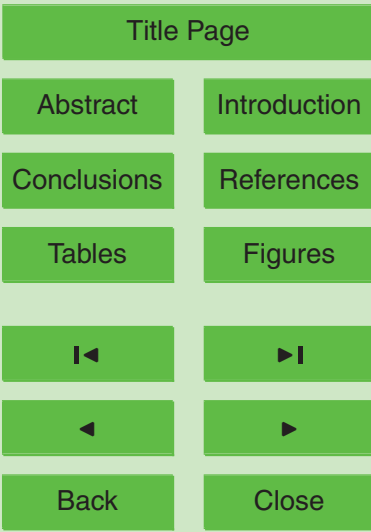

Full Screen / Esc

Fig. 4. Wind directions during rainfall hours at Sutton Bonington over the sampling period.

Printer-friendly Version

Interactive Discussion 

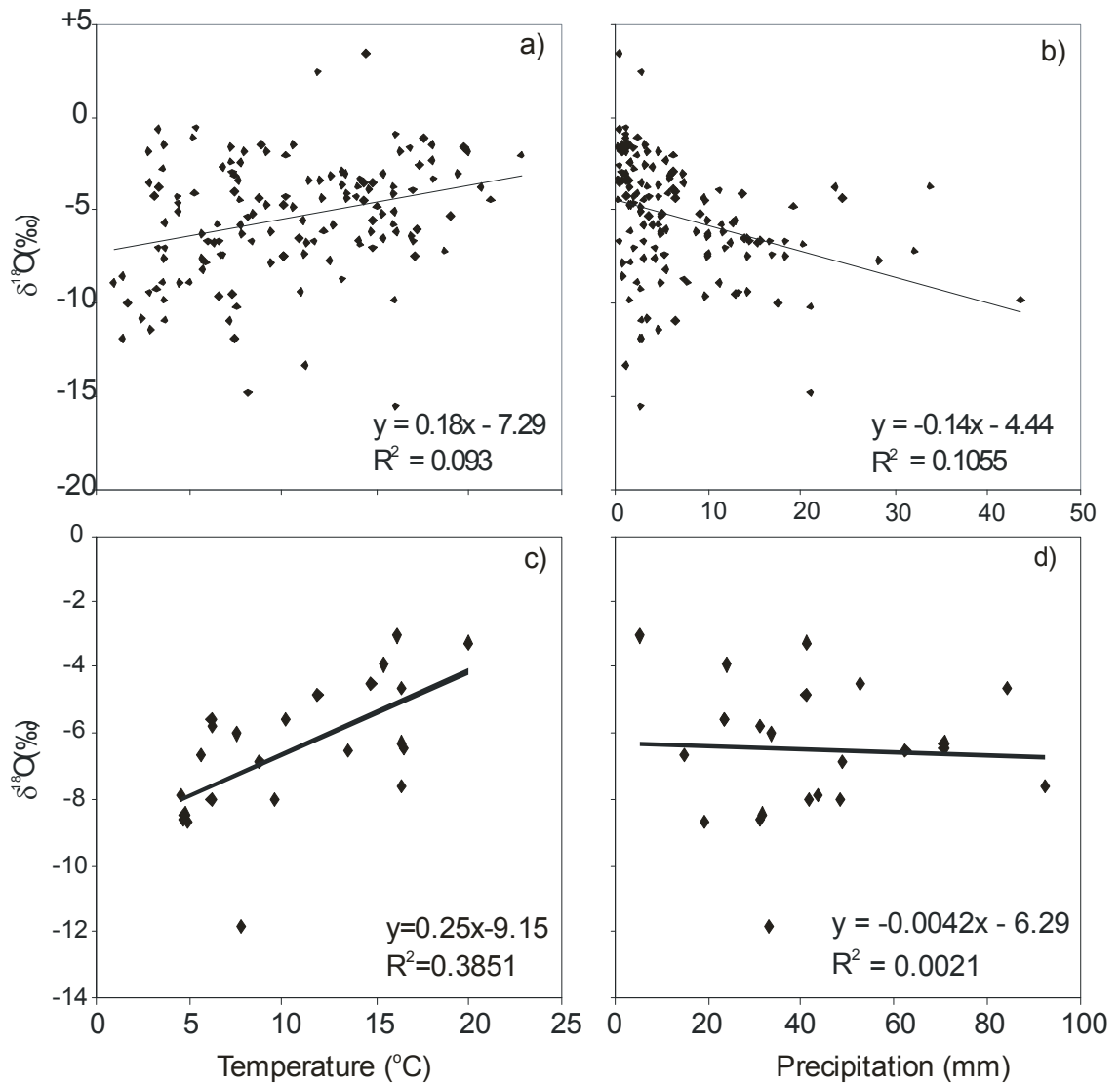

Fig. 5. Differences in the relationship between $\delta^{18} \mathrm{O}_{p}$ and temperature and precipitation amount for individual sample data (a and $\mathbf{b}$ ) and mean monthly values (c and $\mathbf{d}$ ) at Sutton Bonington.

\section{HESSD}

4, 2403-2423, 2007

$\delta^{18} \mathrm{O}$ and $\delta^{2} \mathbf{H}$ variability in UK rainfall

M. D. Jones et al.

Title Page

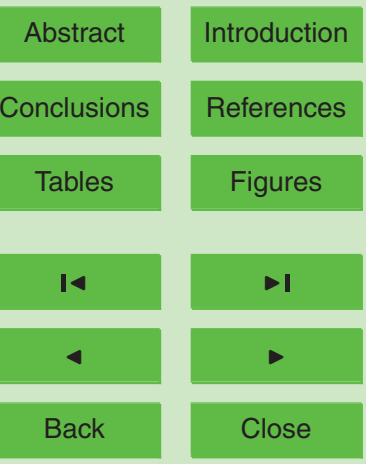

Full Screen / Esc

Printer-friendly Version

Interactive Discussion 


\section{HESSD}

4, 2403-2423, 2007

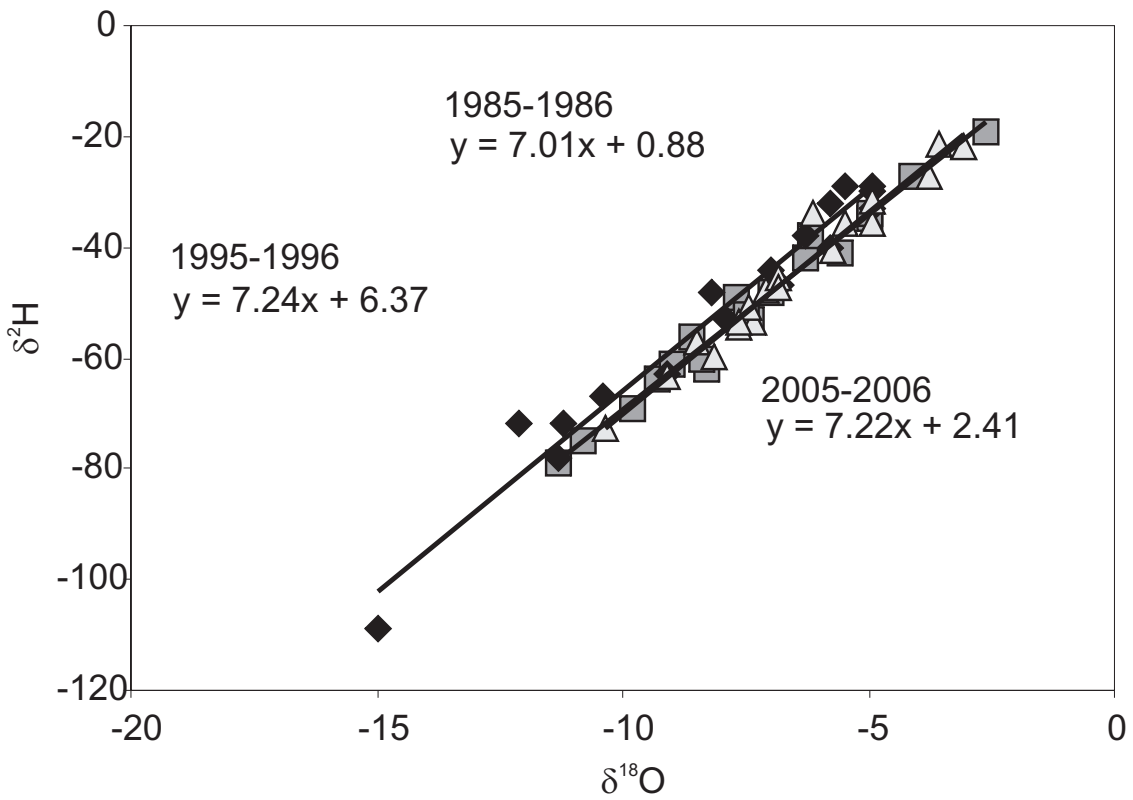

$\delta^{18} \mathrm{O}$ and $\delta^{2} \mathrm{H}$ variability in UK rainfall

M. D. Jones et al.

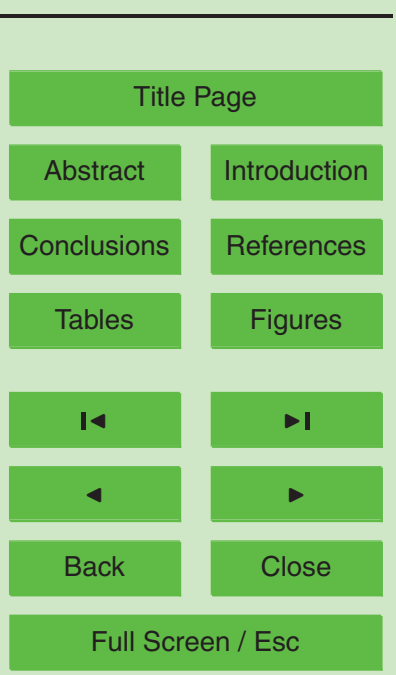

Fig. 6. Differences in the meteoric water lines for 1985-1986 (squares), 1995-1996 (diamonds) and 2005-2006 (triangles) from Keyworth.

Printer-friendly Version

Interactive Discussion 